MAGDALENA ŻYŁA

Doktorantka w Katedrze Eklezjologii UPJPII (Kraków)

e-mail: magdalena.anna@poczta.onet.pl

DOI: http://dx.do.org/10.18290/rt.2019.66.9-13

\title{
RELACJA Z MIĘDZYNARODOWEGO SYMPOZJUM NAUKOWEGO „KOŚCIÓŁ I MISJA” \\ Rzym, 18-19 lutego 2019 r.
}

Kościół ze swojej natury jest misyjny, gdyż bierze początek z misji Syna i Ducha Świętego, zgodnie z zamysłem Boga Ojca - czytamy w soborowym dekrecie Ad gentes divinitus. Pod koniec XX i na początku XXI wieku sam termin „misja” nabrał bardziej teologicznego znaczenia i stał się przedmiotem pogłębionej refleksji. Uwolniony został od kontekstu politycznego, gospodarczego czy kulturowego i przywrócony w obszar przede wszystkim relacji z Bogiem Trójjedynym. Misja wypływa z natury samego Boga, którego pragnieniem jest tworzenie komunii z każdym człowiekiem. Zaangażowanie misyjne Kościoła zawsze jest oznaką jego żywotności, a zanik - duchowego kryzysu. Właśnie misji poświęcona została ostatnia konferencja naukowa zorganizowana przez Katedrę Eklezjologii Uniwersytetu Papieskiego Jana Pawła II w Krakowie i Komitet Nauk Teologicznych PAN. Była to jubileuszowa, dziesiąta z serii, konferencja naukowa inicjowana przez środowisko krakowskich eklezjologów.

Pałac Doriów mieszczący się przy Piazza Venezia, czyli w samym centrum Wiecznego Miasta, w którym od 1938 roku działa stacja naukowa Polskiej Akademii Nauk, przez dwa dni rozbrzmiewał gorącą debatą teologiczną. Prelegenci, wśród których znaleźli się naukowcy z ośrodków rzymskich, krakowskich, lubelskich, wrocławskich, warszawskich i opolskich, ukazali barwną panoramę zagadnień związanych z misyjnością Kościoła, uwzględniając jej początki, refleksję towarzysząca zjawisku przez wieki oraz rozmaite konteksty, w których realizuje się ona po dziś dzień.

W dniu rozpoczęcia obrad gości powitał prof. dr hab. Piotr Salwa, kierownik placówki. Krótko przedstawił historię instytucji i jej bieżącą działalność oraz przywołał poprzednią konferencję „Kościół i dar pokoju”, zorganizowaną tamże w 2016 roku również przez Katedrę Eklezjologii UPJPII. Następnie głos zabrał o. prof. dr hab. Andrzej Napiórkowski OSPPE, kierownik Katedry Eklezjologii UPJPII i spiritus movens całej serii przedsięwzięć, dziękując za wysiłek intelektualny oraz dyscyplinę prelegentów, które zaowocowały nie tylko referatami, ale także publikacją książkową oddaną właśnie do rąk czytelników ${ }^{1}$. We wprowadzeniu zauważył, że

\footnotetext{
${ }^{1}$ Misja: istota i chwała Kościoła katolickiego, red. A.A. Napiórkowski OSPPE, Wydawnictwo Naukowe Uniwersytetu Papieskiego Jana Pawła II, Kraków 2019. Jest to dziesiąty tom 
najpierw należy odpowiedzieć na pytanie: kim jest Kościół? Odpowiedź taka jest trudna, gdyż Kościół to rzeczywistość dynamiczna, która nam, ludziom, stawia ciągłe wyzwania. Połączenie boskiego z ludzkim, dokonujące się w Kościele, udało się tak naprawdę tylko Najświętszej Maryi Pannie.

Przedpołudniową sesję poprowadził ks. prof. dr hab. Wojciech Zyzak, rektor UPJPII. Pierwsze wystapienie ks. prof. dr. hab. Mariusza Rosika z wrocławskiego PWT pt. „Synagoga a rodzący się Kościół” ukazało drogę rozejścia się tych dwóch rzeczywistości. Zagadnienie misji było niewątpliwie jednym z faktorów przyspieszających oddalenie się od siebie judaizmu i chrześcijaństwa. W drugim wystapieniu ks. prof. dr hab. Andrzej Gieniusz CR z rzymskiego Università Urbaniana przedstawił zagadnienie misji według Apostoła Narodów. To Jezus definiował doświadczenie Pawła i jego misję ewangelizacyjną; interioryzacja kontaktu z Chrystusem, którą wyrażał wielokrotnie słowami „we mnie”, kierowała cała jego działalnością misyjną. Kolejny referat, pt. „Ojcowie greccy i łacińscy o głoszeniu chrześcijańskiego Boga”, który przedłożył ks. prof. dr hab. Piotr Szczur z KUL-u, skupił się na trzech greckich terminach: kerygmat, keryx, kerytto-kerysso, wokół których przekrojowo został zarysowany temat w ujęciu patrystycznym. Mowa była o dwóch rodzajach kerygmatu: słowa i czynu, z czego drugi może realizować się przez życie zgodne z Ewangelią i męczeństwo. Wystąpienie ks. prof. dra hab. Dariusza Tabora CR z krakowskiego UPJPII, zatytułowane „Luksusowe psałterze chrystologiczne XIII stulecia: ewangelizacja elit?”, przybliżyło trzy iluminowane psałterze, arcydzieła książki rękopiśmiennej: psałterz z Trzebnicy, psałterz landgrafa Hermana, psałterz św. Elżbiety oraz ich znaczenie w życiu wielkich ówczesnego świata. Następny referat zaprezentowany został przez o. dr. Marka Piotra Chojnackiego OCist z UPJPII i nosił tytuł: „Edukacyjno-pedagogiczna działalność Kościoła w średniowieczu”. Prelegent z erudycyjnym rozmachem nakreślił ideał człowieka antycznego oraz ten zaproponowany przez chrześcijaństwo, szczególnie wyraźnie zarysowany w średniowieczu. Ostatnie przed przerwą wystąpienie, tym razem w języku włoskim, wygłoszone przez prof. dr. Carmela Dotola z Università Urbaniana pt. „Inculturazione e nuovo umanesimo” („Inkulturacja i nowy humanizm”) dotyczyło zjawiska inkulturacji jako procesu hermeneutycznego odczytującego rzeczywistość z jej oczekiwaniami i trudnościami w świetle Ewangelii. Celem takiego rozumowania jest ponowne określenie sensu życia i powołania człowieka.

Drugą sesję, prowadzoną przez ks. prof. dr. hab. Zygfryda Glaesera z opolskiego WT, rozpoczął swym referatem „Koncepcje Kościoła a realizacja jego misyjności” o. prof. A. Napiórkowski. Zaprezentował w nim przegląd koncepcji Kościoła oraz wynikającego z nich pojmowania misji, od pierwszych wieków chrześcijaństwa aż do papieża Franciszka, ze szczególnym uwzględnieniem papieży XX wieku. Zwrócił uwagę na to, że pierwotny Kościół cały był misyjny, nie było w nim żadnego roz-

z cyklu publikacji Cracoviensis Cogitatio Ecclesialis wydawanego przez kolegium redakcyjne, w skład którego wchodzą obecnie: Marek Piotr Chojnacki OCist, ks. Józef Morawa, Andrzej A. Napiórkowski OSPPE, ks. Paweł Pielka. Warto nadmienić, iż tytuł książki jest inny niż tytuł sympozjum, gdyż teksty tam zamieszczone omawiają zjawisko jeszcze szerzej. 
działu na Kościół i misję. Drugi referat, autorstwa ks. dr. Józefa Morawy z UPJPII, pt. „Treść misji Kościoła dzisiaj” zawierał prezentację eklezjologicznych paradygmatów misyjnych przyświecających tej działalności. Prelegent ujął Kościół w jego następujących wymiarach: jako miejsce prawdy, pokoju, wolności, odpuszczenia grzechów, jedności. Następnie głos zabrał ks. prof. W. Zyzak, rektor UPJPII, prezentując opracowanie zatytułowane „Duchowość misji”. Zaznaczył on, że w zasadzie wszystko, co zaprezentowane zostało do tej pory, dotyczy tematu duchowości misji. Najkrócej można to podsumować zdaniem Marie-Dominique’a Chenu OP: „Kościół jest sobą, gdy wychodzi poza siebie”. Misyjność, jako zespół postaw pobudzanych przez Ducha Świętego, będzie zawsze dążyć do przekraczania siebie i budowania jedności. Przedostatni w tej sesji referat ks. prof. dr. hab. Antoniego Nadbrzeżnego z KUL-u nosił tytuł „Pojednanie jako misja Kościoła” i wpisywał się w nurt teologii kontekstualnej, z założenia niedokończonej i pobudzającej do rachunku sumienia każdego z ludzi Kościoła. W czasach szybkiego przepływu informacji żadna ze wspólnot lokalnych nie może uchylić się od odpowiedzialności za inną wspólnotę, zwłaszcza cierpiącą i będącą w potrzebie. Ostatnie zaś wystąpienie, zatytułowane „Posłannictwo kościelne w ujęciu Hansa Ursa von Balthasara”, wygłosił ks. dr Paweł Pielka z UPJPII. W zaprezentowanej myśli szwajcarskiego teologa posłuszeństwo jawi się jako centralne zagadnienie zarówno chrystologiczne, jak i eklezjologiczne oraz misjologiczne. Choć posłuszeństwo jest dziś, w epoce szczególnego wyczulenia na autonomię jednostki, traktowane jako coś nieaktualnego lub do przyjęcia jedynie pod warunkami, które właściwie podważają jego sens, jest ono podstawowym warunkiem płodności misji.

Dyskusja, odbywająca się po przedstawieniu referatów, dotyczyła przede wszystkim kontekstualności, pojednania i posłuszeństwa. Ks. dr hab. Damian Wąsek z UPJPII zaznaczył, że kontekstualność zakłada napięcie między wiernością formułom dogmatycznym a wiernością współczesności. O. prof. A. Napiórkowski wyraził pogląd, że teologia kontekstualna niesie prawdopodobnie większe zagrożenia niż zyski i należy zachować wobec niej ostrożność. Podkreślił, że nie ma czegoś takiego jak Kościoły narodowe. Ks. prof. W. Zyzak zapytał, czy we współczesnym krytykowaniu papieża Franciszka jest w ogóle wiara i posłuszeństwo. Być może za dużo tłumaczymy kontekstem kulturowym, z którego pochodzi Jorge Mario Bergoglio. Ks. D. Wąsek zastanawiał się, czy istnieje w ogóle coś takiego jak teologia niekontekstualna. Obecny na sali p. Leszek Mikos, niebędący reprezentantem środowiska teologów zapytał, czy jeśli teologia jest tylko i wyłącznie kontekstualna, to czy w ogóle jest jakaś teologia. Ks. prof. dr hab. Krzysztof Kościelniak z UPJPII odpowiedział, że owszem, teologia jest kontekstualna, jednakowoż całość tworzy jeden depozyt wiary. Ks. prof. A. Nadbrzeżny dopowiedział, że pluralizm teologiczny jest konieczny, ale ma swoje granice. Na tym dyskusję zakończono, by z nowymi siłami kontynuować ją następnego dnia.

Ks. prof. M. Rosik poprowadził pierwszą wtorkową sesję. O. prof. dr hab. Bazyli Degórski OSPPE z rzymskiego Università Angelicum rozpoczął ją referatem w języku włoskim zatytułowanym „La Chiesa e la vita monastica in sant’ Agostino” (,Kościół a życie monastyczne u św. Augustyna"), w którym zaprezentował wizję życia mniszego zaproponowaną przez biskupa Hippony jako życia w Kościele i dla jego 
posłannictwa. Następnie głos zabrała prof. dr Margherita M. Rossi, również z Angelicum, prezentując referat pt. „Una visione di missionarietà in alcuni scritti di san Tommaso d'Aquino” (,Koncepcja misji w niektórych pismach św. Tomasza z Akwinu"). Przedstawiła misjologiczną refleksję obecną w twórczości teologicznej Akwinaty, podkreślając ruch od naśladowania Jezusa do Jego przepowiadania. Po niej głos zabrał ks. prof. dr hab. Jarosław Różański OMI z warszawskiego UKSW i przedłożył referat „Misyjność ad intra i ad extra w Czadzie i Północnym Kamerunie”, wprowadzając zebranych w misyjne praxis Afryki. Następnie ks. prof. dr hab. Paweł Bortkiewicz TCh z WT UAM w Poznaniu przedstawił referat pt. „Globalizacja wyzwaniem dla misji Kościoła katolickiego”. Zwrócił uwagę na ambiwalencję samego procesu oraz trudności, jakie stają dziś przed Kościołem. Apatia - misja - agresja - tak zdaniem prelegenta prezentuje się oś, po której porusza się każdy misjonarz, przy czym misja jest pożądanym stanem idealnym, a skrajności należy unikać.

Po przerwie ostatnią już sesję poprowadził ks. dr J. Morawa. W pierwszym wystąpieniu „Ewangelizacja, reewangelizacja i ekumenizm” ks. prof. dr hab. Z. Glaeser wyraził dobitnie, że ekumenizm jest imperatywem chrześcijańskiego sumienia, a nie tylko zajęciem dla hobbystów, gdyż każdy podział w Kościele jest przeciw woli Jezusa. W pięciu paradygmatach przedstawił drogę, która może przybliżać do jedności, o ile przyzywać będzie się w Kościele Ducha Świętego. Prof. dr hab. Krzysztof Leśniewski z KUL-u przedstawił problem „Misji u prawosławnych”. Metanoia, czyli przemiana umysłu, jest tam najważniejszym elementem. Z wiary rodzi się kult, z kultu kultura. Misja w prawosławiu dotyczy każdego chrześcijanina według darów, które posiada. Ostatni referat wygłosił ks. prof. dr hab. K. Kościelniak z UPJPII. W swoim przedłożeniu pt. „Misja Kościoła w Azji” naszkicował skomplikowaną panoramę Kościołów największego z kontynentów oraz sytuację misji w poszczególnych kontekstach kulturowych i religijnych. Zaznaczył, że tam, gdzie panuje prawo szariatu, ograniczenie dla misji chrześcijańskich jest znaczne. Podsumowania całości obrad dokonał o. dr M. Chojnacki. Syntetycznie zebrał myśli wszystkich prelegentów i domknął część referatową, otwierając dyskusję.

Kolejna życzliwa debata teologiczna dotyczyła ekumenizmu, otwartej i zamkniętej tożsamości Kościoła, wyjścia chrześcijaństwa z Europy, a także sytuacji w Cerkwi prawosławnej, o której opowiedział znawca, prof. K. Leśniewski. Zaznaczono, że w religii nie mogą dominować funkcje inne niż zbawienie. Gdy tak się dzieje, pojawiają się poważne problemy.

Drugi i ostatni dzień obrad, prowadzonych w Wiecznym Mieście, pozostawił prelegentów i uczestników ubogaconymi intelektualnie, duchowo i kulturowo, dając jednocześnie odczuć pewien niedosyt, który kieruje oczekiwanie ku kolejnej konferencji organizowanej przez Katedrę Eklezjologii UPJPII. Mamy nadzieję, że spotkamy się za rok w jeszcze większym gronie, a czas pomiędzy kolejnymi dyskusjami teologicznymi będzie przestrzenią asymilacji treści już poznanych oraz przygotowaniem do kolejnej debaty podejmowanej dla chwały Boga i dobra Kościoła, naszej Matki. 